高温超伝導 SQUID を用いた先端バイオ・非破壊

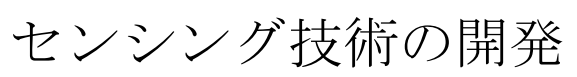

圓福 敬二*1,†，神鳥 明彦 ${ }^{* 2}$, 安達 成司 ${ }^{* 3}$, 塚田 啓二*4, 田中 三郎 ${ }^{* 5}$

\title{
Advanced HTS SQUID System for Biomedical Diagnosis and Nondestructive Testing
}

\author{
Keiji ENPUKU $^{* 1, \dagger}$, Akihiko KANDORI $^{* 2}$, Seiji ADACH ${ }^{* 3}$, Keiji TSUKADA $^{* 4}$ and Sabro TANAKA ${ }^{* 5}$
}

Synopsis: As part of the JST project, we have been developing advanced high-temperature superconducting quantum interference devices (HTS SQUIDs) for biomedical diagnosis and nondestructive testing. In this paper, we show the recent progress of our research. First, we show a highly sensitive and reliable HTS SQUID sensor. Using HTS SQUIDs, we have developed advanced magnetic-sensing systems. We show the results of biosensing systems, such as magnetocardiogram measurement of small animals, magnetic immunoassay and low field MRI. We also show the results of nondestructive testing systems, such as evaluation of solar-cell panels, rapid and quantitative detection of water, and detection of small magnetic contamination. We demonstrate the promising results of these magnetic-sensing techniques.

Keywords: HTS SQUID, biosensing, nondestructive testing, magnetic-sensing system

(Some figures in this article may appear in colour only in the electronic version)

\section{1. はじめに}

磁気は非接触かつ非破壊で試料内部の信号検出が可能で あるという大きな利点を有する。このため、磁気的手法に よるバイオ・非破壊検査技術は他の競合技術では不可能な 性能や機能を実現することができ、この優位性を利用した 種々の検査システムの開発が国内外で精力的に行われてい る。

Received October 1, 2012

*1 九州大学 超伝導システム科学研究センター

于819-0395 福岡県福岡市西区元岡 744

Kyushu University, 744 Motooka Nishi-ku, Fukuoka 819-0395,

Japan

*2 (株) 日立製作所 中央研究所

干185-8601 東京都国分寺市東恋ヶ窪 1-280

Hitachi Ltd., 1-280, Higashi-Koigakubo Kokubunji, Tokyo

185-8601, Japan

*3 (公財) 国際超電導産業技術研究センター 超電導工学研究所

干135-0062 東京都江東区東雲 1-10-13

Superconductivity Research Laboratory-ISTEC, 1-10-13

Shinonome, Koto-ku, Tokyo 135-0062, Japan

${ }^{*} 4$ 岡山大学大学院自然科学研究科

干700-8530 岡山県岡山市北区津島中 3-1-1

Okayama University, 3-1-1, Tsushimanaka, Kitaku, Okayama

700-8530, Japan

*5 豊橋科学技術大学工学部 エコロジー工学系

T441-8580 愛知県豊橋市天伯町雲雀ヶ丘 1-1

Toyohashi University of Technology, 1-1 Hibarigaoka Tempakucho Toyohashi, Aichi 441-8580, Japan

† E-mail: enpuku@sc.kyushu-u.ac.jp
SQUIDは超高感度な磁気センサとして知られており、そ の高感度性を用いれば、磁気的手法による先端センシング システムの開発が可能となる。既に、LTS SQUIDは先端科 学計測の分野で大きな実績を有しているが、産業応用への 展開を可能とするためには、HTS SQUIDを用いたセンシ ングシステムの開発が不可欠である。

このため、JST の S-イノベプログラム「超伝導システ ムによる先進エネルギー・エレクトロニクス産業の創出」 の中の一課題として、「高温超伝導 SQUID を用いた先端 バイオ・非破壊センシング技術の開発」を行っている。本 研究では、HTS SQUID センサのポテンシャルを最大限引 き出すことにより、低温 SQUID に匹敵する高感度性と高 い信頼性を持つ SQUID システムを開発することを一つの 目標としている。さらに、開発した SQUID センサシステ ムをバイオ計測や非破壊センシングの応用機器へと展開す ることをもう一つの目的としている。本研究が開始してか ら 3 年が経過しており、本論文ではこれまでに得られてい る主な成果について紹介する。

\section{2. 研究課題の概要}

本研究の主な開発課題をFig. 1に示す。HTS SQUIDシス テムに関しては、これまで開発してきたジョセフソン接合 の作製技術や積層化技術を高度化し、高感度で耐磁場特性 に優れた HTS SQUIDを開発する。すなわち、バイオ計測 


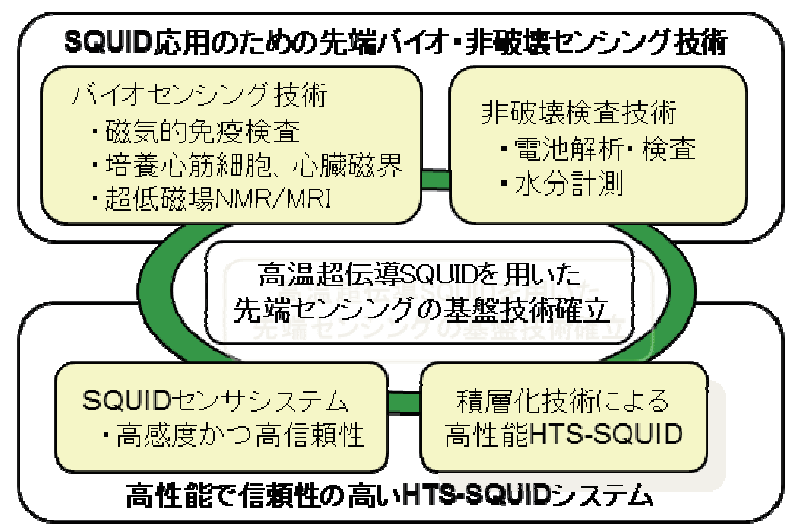

Fig. 1 Aims of the research project.

用の集積化SQUID と非破壊検査用の検出コイル分離型 SQUIDを開発する。また、雑音除去法や磁界補償法などを 高度化し、磁場中動作が可能なセンサシステムを開発す る。

バイオセンシングシステムとしては、医療診断や再生医 療のためのセンシング技術を開発し、免疫検査、培養心筋 細胞検出、心磁検出、および超低磁場NMR/MRIへの応用展 開を図る。また、非破壊検査システムとしては、エネル ギー分野で重要となる電池の分析・評価、農業分野等で重 要となる水分量の評価、および磁性不純物の検査、のため の検査システムを開発する。これらのプロトタイプの開 発・評価を通して、従来にない高性能と新機能を有する先 端バイオ・非破壊センシング技術を開拓し、超伝導センシ ング機器の基盤技術を確立することを目標としている。

なお、本研究に参画している研究機関と研究代表者は、 九州大学 (圓福敬二)、日立製作所 (神鳥明彦)、日立ハイ テクノロジーズ（鈴木博之）、（公財）国際超電導産業技術 研究センター（安達成司）、岡山大学（塚田啓二）、豊橋技 術科学大学 (田中三郎)、筑波大学 (青沼和隆)、首都大学 東京（関原謙介）であり、8機関の共同研究により研究課 題を推進している。

\section{3. 高性能 HTS SQUID センサ}

これまでに国際超電導産業技術研究センターにおいて、 高温超伝導デバイスのための積層化技術が開発されてきた。 この技術を改良することにより、高感度で耐磁場特性に優 れた HTS SQUID センサを開発している ${ }^{1-3)}$ 。

\section{1 バイオセンシング用集積化 SQUID}

Fig. 2(a)に開発したバイオセンシング用 SQUID センサを 示す。図に示すように $5 \mathrm{~mm}$ 角の検出コイルを差動形に結 合したグラディオメータとなっている。検出コイルは SQUID インダクタンスに直接接続されており、いわゆる直 接結合型の磁気センサである。なお、Fig. 2(b)に示すよう にジョセフソン接合としてはランプエッジ型を用いており、 7 層の酸化物薄膜で構成されている。このセンサの雑音特
性（磁束雑音）は、Fig. 2(c)に示すように white noise で 3 $\mu \Phi_{0} / \mathrm{Hz}^{1 / 2}$ が、また 1/f noise として $f=1 \mathrm{~Hz}$ において 20 $\mu \Phi_{0} / \mathrm{Hz}^{1 / 2}$ が得られている。これらの值はセンサの磁界雑音 としては、 $60 \mathrm{fT} / \mathrm{Hz}^{1 / 2}$ と $400 \mathrm{fT} / \mathrm{Hz}^{1 / 2}$ に対応する。

磁気センサの性能をさらに向上させるためには、Fig. 3 に示すように、検出コイルからの磁界信号を入力コイルを 介して磁気的に伝達することが有効である。このため、20 巻きの薄膜入力コイルを $200 \times 200 \mu \mathrm{m}^{2}$ サイズの SQUID 素子 上に作製した、入力コイル集積型 SQUID センサを開発し た。

この入力コイルを $15 \times 15 \mathrm{~mm}^{2}$ の検出コイルと結合した 場合の性能を Fig. 3 に示す。同図に示すように white noise として $8 \mathrm{fT} / \mathrm{Hz}^{1 / 2}$ が得られており、HTS SQUID としては 世界最高水準のレベルの值である。また、この性能は LTS SQUID に匹敵するものである。ただし低周波側におい て、いわゆる $1 / f$ 雑音が顕著に見られる。この $1 / f$ 雑音の 低減が今後の課題である。
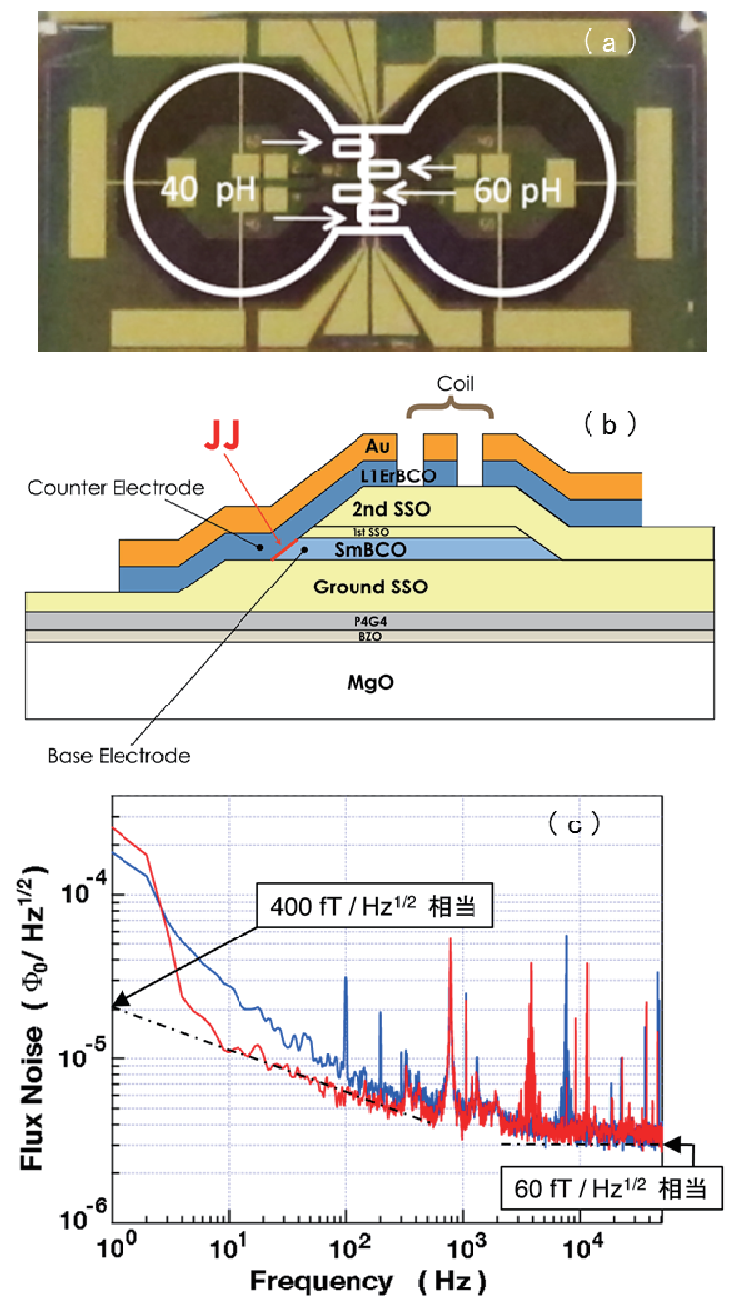

Fig. 2 Integrated HTS SQUID sensor for biosensing applications: (a) photo of the sensor, (b) ramp-edge Josephson junction and (c) noise characteristics. 


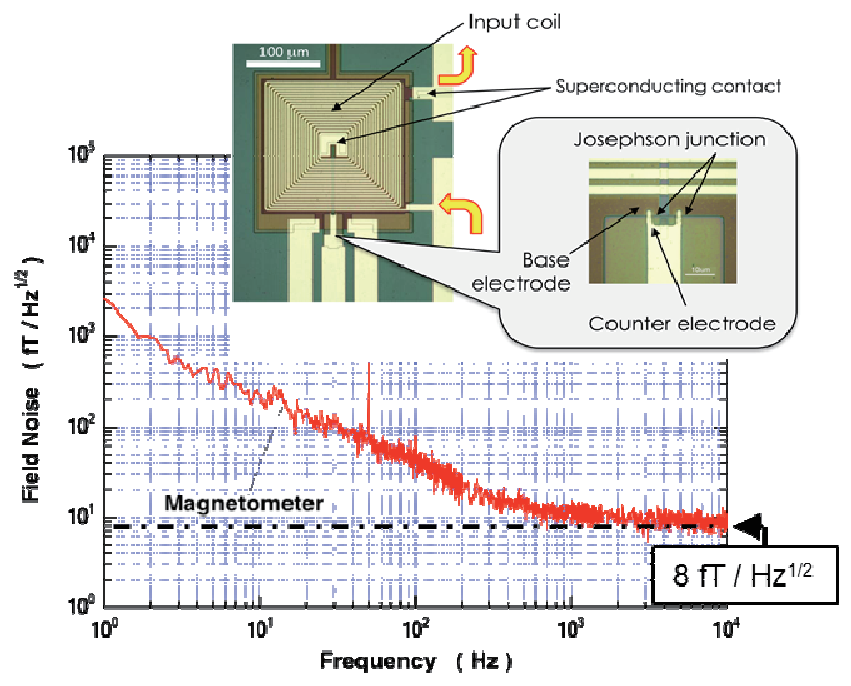

Fig. 3 HTS magnetometer using a multi-turn input coil.

\section{2 非破壊検査用分離型 SQUID}

非破壊検査においては、用途に応じて検出コイルのサイ ズが大きく異なる。このため、Fig. 4(a)に示すような検出 コイルと SQUID を分離した分離型 SQUID システムを開発 した。Fig. 4(a)の破線で囲まれた部分、すなわち、入力コイ ルと SQUID を一体化したセンサモジュールを開発した。

Fig. 4(b)にその外観写真を示す。

SQUID センサには直接結合型のグラディオメータを用い ている。また、薄膜入力コイル（70 turn） は別基板上に作 製して、両者を張り合わせるフリップチップ方式により磁 気信号を伝達している。この場合の SQUID と入力コイル の相互インダクタンスは 1〜2 nH であり、磁気信号の効率 的な伝達を可能とし、応用システムの開発に十分な值を実 現している。

このセンサモジュールに検出コイルを接続することによ り種々の計測システムを開発することができる。現在、室 温や液体窒素温度に冷却した銅検出コイル、および高温超 伝導テープを用いた検出コイルを用いた種々の計測システ ムを開発している。Fig. 5 に分離型 SQUID システムの磁界 雑音の測定例を示す。この場合には、検出コイルとしては 液体窒素に冷却した銅検出コイルを用いている。コイルの 直径は $50 \mathrm{~mm}$ 、巻数は 150 である。なお、高周波における コイルの渦電流損を低減するため、リッツ線を用いてコイ ルを作製している。また、検出コイルと入力コイルの間に 共振用のコンデンサ $C$ を挿入して、共振周波数での高感度 な計測を行うシステムとなっている ${ }^{4,5)}$ 。

Fig. 5 に示寸ように、本システムでは $10 \mathrm{kHz}$ 帯において 数 $\mathrm{fT} / \mathrm{Hz}^{1 / 2}$ の磁界感度が得られており、HTS SQUIDを用い たものとしては世界最高感度を達成している。また、LTS と比較してもそん色のない結果となっている。この磁界感 度は低磁場 NMR などの応用に十分なものである。なお、

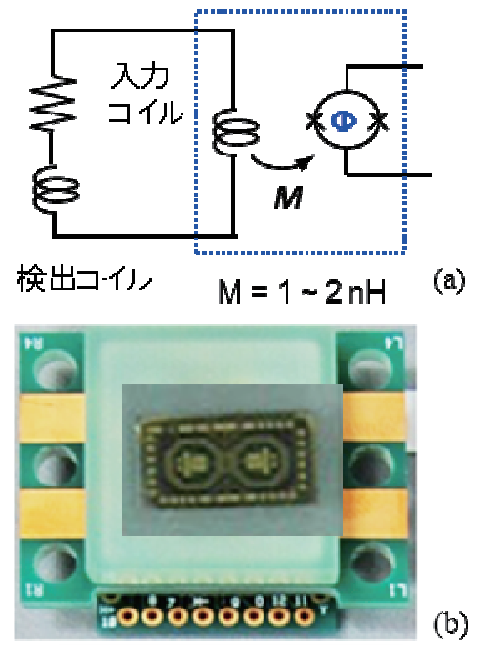

Fig. 4 HTS SQUID module for the coupling to the pickup coil: (a) equivalent circuit and (b) photo of the module.

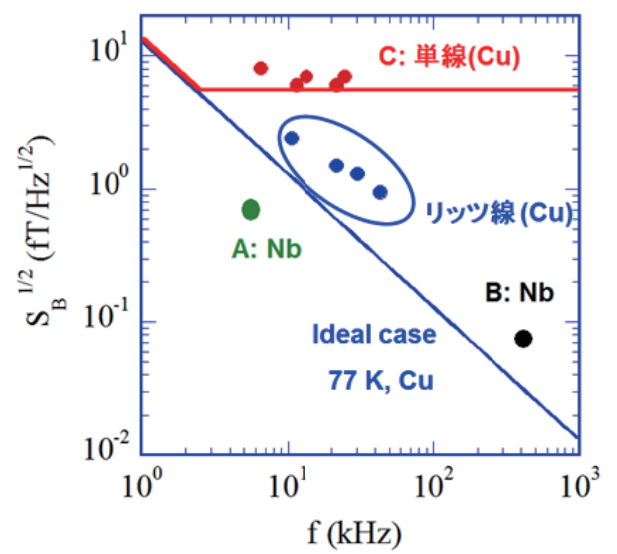

Fig. 5 Noise characteristics of the magnetometer. The magnetometer was made by coupling the pickup coil to the HTS SQUID module shown in Fig. 4.

図には銅単線でコイルを作製した場合の結果 ${ }^{6}$ も示してい る。リッツ線を用いることによりセンサの低雑音化が可能 なことが分かる。

\section{4. センシングシステム}

前述した高性能な HTS SQUID を用いて種々のバイオ・ 非破壊センシング技術の開発を行っており、以下に、これ までに得られている主な成果について述べる。

\section{1 バイオセンシングシステム}

\subsection{1 生体磁気計測システム}

小動物から人体までのトータルな心機能の診断・解析の ための生体磁気計測システムを開発している。小動物の心 磁計測は薬物の毒性評価などのために重要である。このた め、Fig. 2 に示したバイオセンシング用の集積化 SQUID を 用いた小動物の生体磁気計測システムを開発した。開発し たシステムを用いて、17 週齢で体重約 $50 \mathrm{~g}$ のマウスの心 


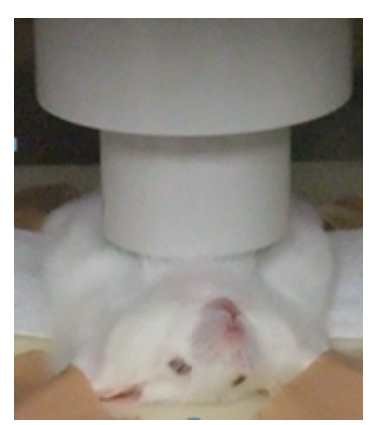

(a)

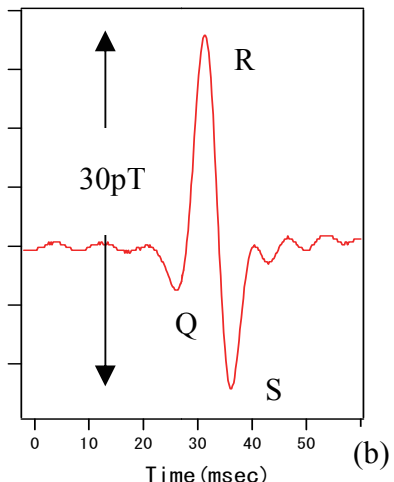

(b)
Fig. 6 Magnetocardiogram (MCG) of a mouse: (a) photo of the measurement and (b) MCG signal.

臟磁界を計測した例を Fig. 6 に示す。測定においては 0.1 $\mathrm{Hz}$ から $150 \mathrm{~Hz}$ のバンドパスと $50 \mathrm{~Hz}$ のノッチフィルタを 用い、64 回の加算平均を行った。同図に示すように、明瞭 な心磁波形（信号強度 $30 \mathrm{pT}$ 程度）の計測を可能としてい る。

さらに、人体の心臟磁界から心疾患の診断を迅速・正確 に行うための磁気イメージング手法を開発している。心疾 患をより正確な解剖学的な位置で診断することを目的に、 これらのイメージング技術を臨床現場と協力して開発を 行っている。その一例として、心磁図と CT 画像を合成し て疾患部位を特定するイメージング技術を世界に先駆けて 開発し、その有効性を検証している。

\subsection{2 磁気的免疫検査システム}

免疫検査は疾患由来のタンパク質や病原菌などのバイオ 物質を検出するための検查手法であり、血液検查などの医 療診断において多く用いられている。本研究では、磁気 マーカーと Fig. 2 に示したバイオセンシング用 SQUID を 組み合わせた磁気的な免疫検査システムを開発している。 この磁気的手法には従来の光学的手法には無い高速性と高 感度性が期待されている。

Fig. 7(a) に開発している検査システムの模式図を示 す ${ }^{7-9)}$ 。図に示寸様に、固定用ポリマー粒子（直径 $3 \mu \mathrm{m}$ ) に検查すべきバイオ物質（抗原： target）を結合させる。そ の後磁気マーカーを投入すると、磁気マーカーの一部は抗 原と結合し、このマーカーを結合（Bound）マーカーと呼 ぶ。溶液中には未結合の磁気マーカーも存在しており、こ れを未結合 (Free) マーカーと呼ぶ。従来の光学的手法で は洗浄工程により両者を分離しており、この工程は $\mathrm{B} / \mathrm{F}$ 分 離と呼ばれている。この $\mathrm{B} / \mathrm{F}$ 分離の工程は手間と時間がか かるため、この工程を省くことが可能な液相免疫検查法を 開発している。

本手法では、結合マーカーと未結合マーカーの溶液中で のブラウン磁気緩和の違いを利用して、両者が混在した状 態でも結合マーカーのみを検出している。検出の手順は以 下の通りである。最初に反応容器内の磁気マーカーを励起
磁界 $B$ により磁化する。その後容器を回転すると、励起 磁界は $B=0$ となり、ブラウン緩和が開始する。回転中に 未結合マーカーのブラウン磁気緩和は完了し、SQUID セ ンサの直上に達した時にはその信号はゼロとなる。一方、 結合マーカーは回転中も磁気信号を保持寸る。このため、 結合マーカーのみを検出できる。

これらの開発した手法を用いてビオチンと呼ばれるタン パク質の検出害験を行った。Fig. 7(b) に実験結果を示 す。図の横軸はビオチンの個数であり、縦軸は SQUID に より検出した磁気信号である。同図に示寸ように両者はほ ぼ比例しており、液相免疫検査が正常に行われていること を示している。また、この実験では $2 \times 10^{5}$ 個 $/ 40 \mu 1$ のビオ チンの検出に成功した。モル濃度に換算すると $4 \times 10^{-18}$ $\mathrm{mol} / \mathrm{ml}(4$ アトモル $/ \mathrm{ml})$ であり、液相検查法によりこの高 感度性を初めて実証した。また、この結果は従来の BF 分 離を用いた光学的手法に比べても数倍高感度である。な お、参考のため、他の磁気センサ（MR センサ、Flux Gate センサ）を用いた場合の結果も示している。同図に示すよ うに、SQUID を用いることにより、極微量のバイオ物質 の検出が可能となる。

なお、センサー間で測定された磁場が異なる主な理由 は、センサと試料との距離が異なるためである。測定距離 は SQUID では $1.5 \mathrm{~mm}$ である。一方、MR センサと Flux
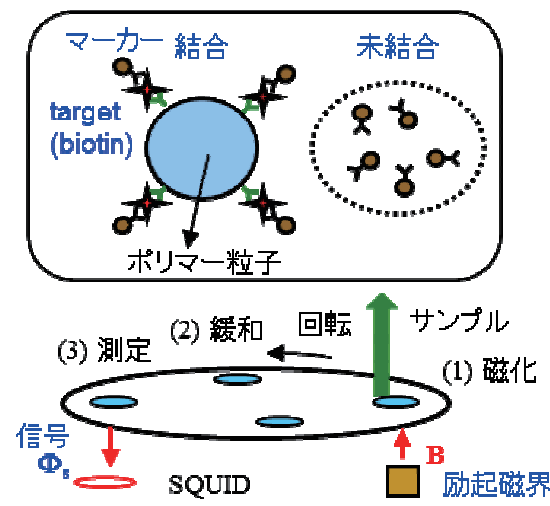

(a)

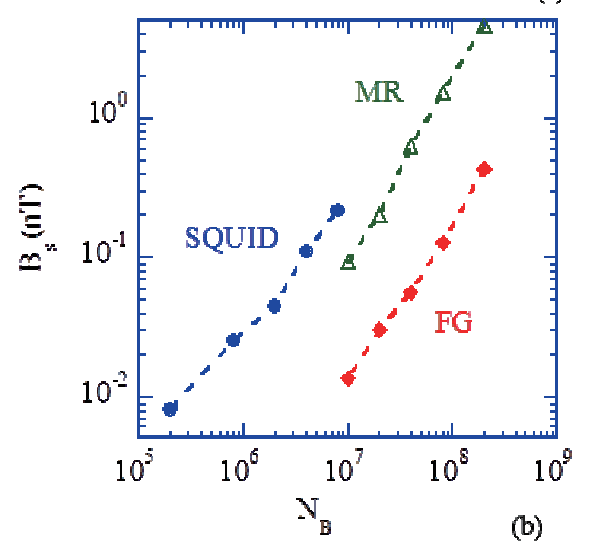

Fig. 7 Liquid-phase immunoassay using a magnetic marker: (a) detection principle and (b) detection of biotin 
gate では、センサを封入しているパッケージの厚さため、 それぞれ $2 \mathrm{~mm}$ と $5 \mathrm{~mm}$ 程度となっている。

\subsection{3 超低磁場 MRI システム}

励起磁界の強さを $50 \mu \mathrm{T}$ から数 $\mathrm{mT}$ 程度にした、超低磁 場 NMR/MRI システムの開発を行っている。超低磁場を 用いることにより、数 $\mathrm{T}$ 程度の強磁場を用いる従来のシ ステムにはない新機能を実現することができる。例えば、

（1）正常細胞と癌細胞の緩和時間の違いを明確に検出で きる、(2) 金属等の影響を受けずに測定できる、などであ る ${ }^{10)}$ 。このため、その基盤となる計測システムを開発して

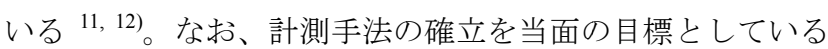
ため、現状では市販の HTS SQUID を用いている。

開発した SQUID NMR 計測システムにより、20 ml の市 水および鉱油のサンプルから、 ${ }^{1} \mathrm{H}-\mathrm{NMR}$ スペクトラムを計 測した結果を Fig. 8(a)に示す。静磁場としては $45 \mu \mathrm{T}$ を与 えており、これに対応するラーモア周波数は約 $1912 \mathrm{~Hz}$ と なる。図に示すように、ラーモア周波数において ${ }^{1} \mathrm{H}-\mathrm{NMR}$ スペクトラムが明瞭に計測されている。水では信号雑音比

（S/N）が約 38、鉱油では 13 となっている。信号強度が 約 3 倍異なるのは、それぞれの分子組成の違いに起因する と考えられる。

Fig. 8(b)には縦緩和時間 $T_{1}$ の測定結果を示す。図に示す ように、水および油に対してそれぞれ $3.3 \mathrm{~s}$ と $0.8 \mathrm{~s}$ の縦緩 和時間 $T_{1}$ 值が得られた。このように、超低磁場 NMR のた めの計測技術を確立することができた。

次にバックプロジェクション法で回転勾配磁場（12 分割） を印加することで 2 次元 MRI 取得を試みた。勾配磁場は $28 \mathrm{nT} / \mathrm{mm}(0.12 \mathrm{~Hz} / \mathrm{mm})$ とした。測定したサンプル写真お よび FID 信号から再構築した MRI の 2 次元画像を Fig. 8(c) に示す。この画像はサンプルの Y-Z 平面への投影とほぼ一 致していることがわかる。

\section{2 非破壊検査システム}

\section{2. 1 磁気的手法による水分検出技術}

HTS-SQUID の特長を用いた高感度でコンパクトな磁化 率計の開発を行っている。基礎的な分析装置というより は、各種産業における迅速な検査装置を目指している。特 に、ポリマーやモルタル、農作物などのサンプル中におけ る水分量は品質管理の上で重要なパラメータであるが、従 来よく使われる加熱法などでは時間がかかるとともに、サ ンプルそのものが測定により変性する問題等があった。そ のため、水の反磁性特性を利用した非破壊で迅速な計測が 可能となる新しい磁気測定方法を試みた。

磁化率の測定では、サンプルに磁場を印加して磁化さ せ、サンプルから発生する磁場を磁気センサで計測する。 本研究では Fig. 4 に示した検出コイル分離型 SQUID を用 いた。すなわち、常伝導の検出コイルで磁化信号を検出 し、磁気シールド中の SQUID に信号を伝達する方式を採 用した。ここで、磁化信号を得る方法としては、磁化した
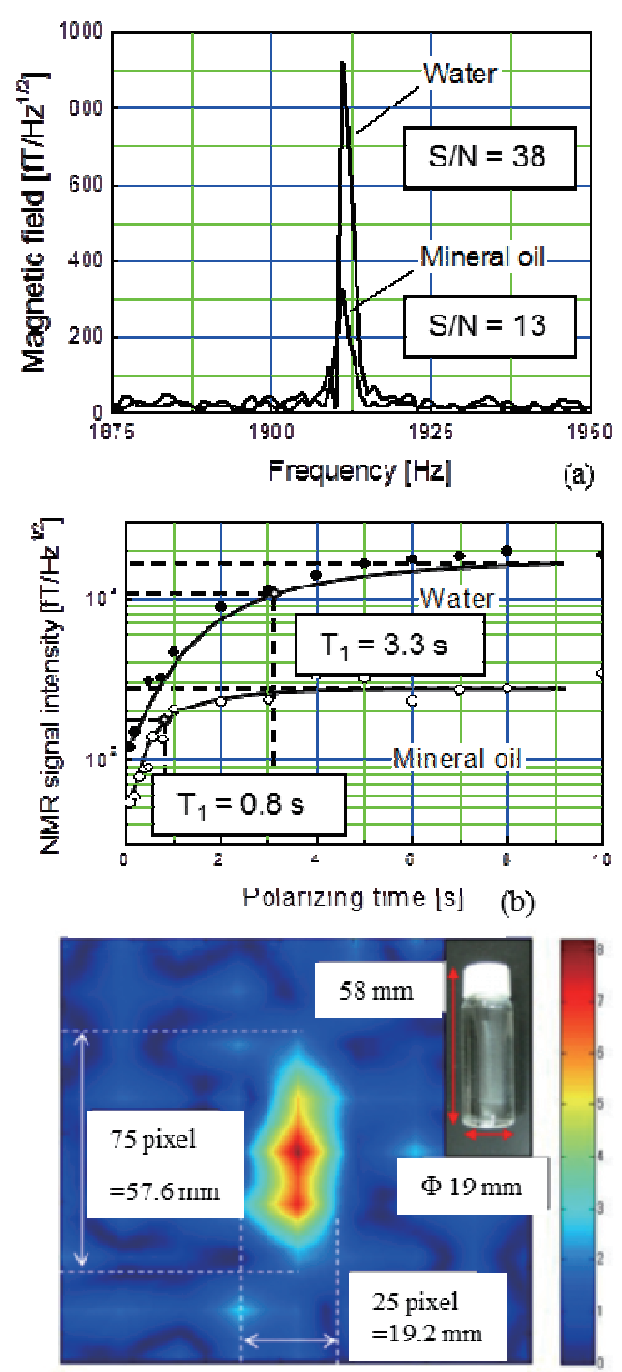

(c)

Fig. 8 Low field NMR using a HTS SQUID: (a) NMR spectrum of water and mineral oil, (b) measurement of $T_{1}$ relaxation time and (c) MRI image of a water sample.

サンプルを動かす振動方法と、印加する磁場を変動させて 磁化を変化させる交流磁場方法がある。本研究ではこれら 振動方式と交流磁場方式を用いた各種磁化特性を計測する コンパクトな装置を開発した ${ }^{13,14)}$ 。

Fig. 9(a)に試作した振動型磁化率計を示す。コンパクト な卓上型となっており、サンプルを横方向に振動させ振動 数に合わせたロックイン検波方式を取っている。本装置を 用いて、モルタルの主成分であるセメントと水の磁気特性 を調べた結果を Fig. 9(b)と Fig. 9(c)に示す。測定条件は印 加磁場 $93 \mathrm{mT}$ 、振動周波数 $2.69 \mathrm{~Hz}$ 、振動振幅 $5 \mathrm{~mm}$ とし た。Fig. 9(b)は振動開始から振動終了までの信号の変動を 示しており、振動中で安定な信号が得られていることが分 かる。水の反磁性は非常に小さいが本装置で計測できてい るのが分かる。さらに振動に対する信号の位相を示したの 

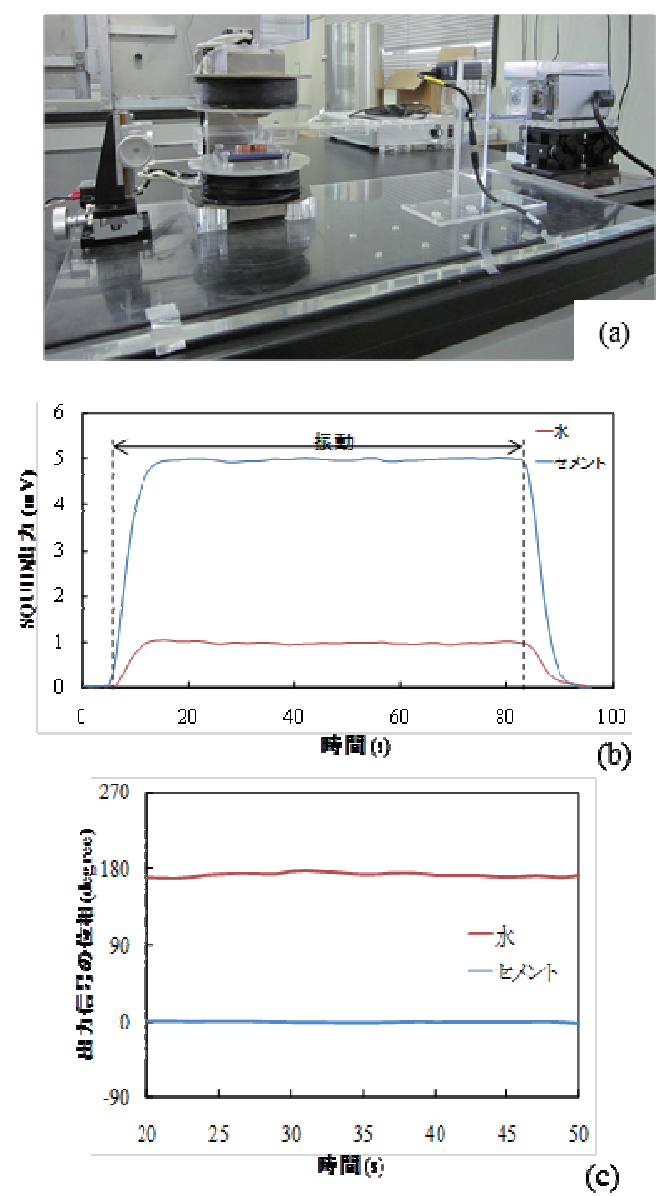

(c)

Fig. 9 (a) Vibrating-sample magnetometer using a HTS SQUID, (b) amplitude and (c) phase of the magnetic signals from water and cement.

が Fig. 9(c)であり、振動を開始してから安定した時間帯で の位相を示している。このようにセメントでは印加磁場と 同位相であり、その一方水は逆の位相つまり反磁性特性を 示していることが分かる。なお、本計測装置の測定感度と しては $10^{-7} \mathrm{emu}$ の高感度が得られているが、現在さらなる 高感度化を進めている。

\section{2.2 太陽電池の評価装置}

太陽電池は持続可能型のエネルギー源として注目されて おり、高効率、高品質の電池を製作するための非破壊検査 計測手法が求められている。そのための新たな方法とし て、太陽電池に周波数変調した電圧を印加して、太陽電池 パネルから発生した磁場を高感度な HTS-SQUID で計測す る装置を開発している。Fig. 10(a)に試作した太陽電池パネ ルの電気特性の評価装置の模式図を示す ${ }^{15)}$ 。パネルの面 上に設置したピックアップコイルにより、パネル平面に平 行な磁場成分 $B_{\mathrm{x}}$ および $B_{\mathrm{y}}$ を捕捉した。この接線成分の磁 場を合成することで太陽電池パネル内の電流分布と磁場分 布が一致する画像化システムを構築した。ここで、磁場信 号はピックアップコイルと直列に接続したインプットコイ

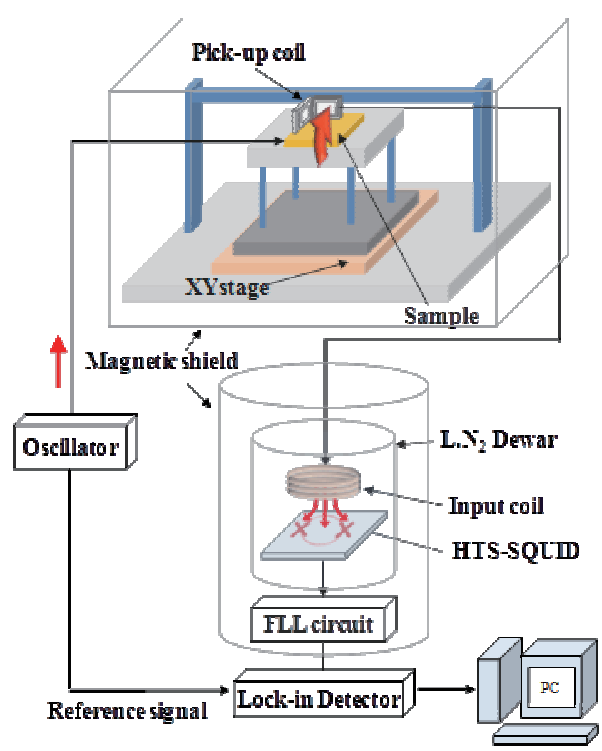

(a)

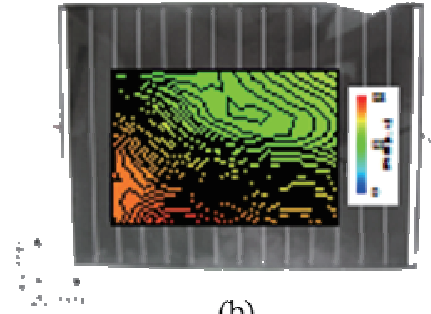

(b)

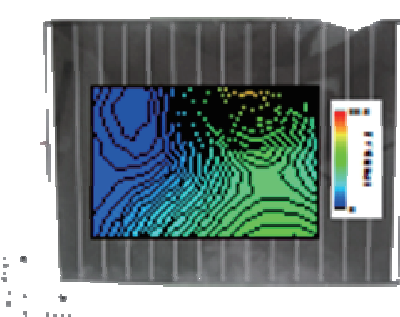

(c)
Fig. 10 (a) NDE system for a solar-cell pane. Spatial distribution of the differential resistance of the solar-cell panel is shown in the cases of (b) open mode and (c) short mode.

ルによって HTS-SQUID へ伝達する検出コイル分離型方式 を取っている。

平行磁場成分はピックアップコイル直下の電流 $I$ に比例 することから、信号は、太陽電池の微分コンダクタンス $d I / d V$ に比例していると考えられる。太陽電池に振幅 0.5 $\mathrm{V}$ 、周波数 $1 \mathrm{kHz}$ の交流電圧と直流バイアス電圧を印加 し、ハロゲン光を照射したときの太陽電池パネルの特性分 布を求めた。Fig. 10(b), (c)は各計測点での微分コンダクタ ンスの逆数である微分抵抗の分布を示したものである。こ こで、Fig. 10(b)は直流バイアス電圧が $8.8 \mathrm{~V}$ の場合の結果 であり、太陽電池パネルの等価回路モデルから、この結果 は開放時の直列抵抗分布を反映していると考えることがで きる。また、Fig. 10(c)は直流バイアス電圧が $1 \mathrm{~V}$ の場合の 結果であり、太陽電池の短絡時の並列抵抗分布を反映して いると考えることができる。このように、本検出方法に よって電池パネルの電気特性の可視化が可能であり、太陽 電池の特性評価に有用である。

\subsection{3 磁気異物検査システム}

磁気異物の磁気的検査手法を確立するため、幅広検出コ イルを用いた Nb 系 SQUID システムを開発した ${ }^{16)}$ 。本シス テムでは、微小磁気粒子を模擬的に移動させる移動装置、 

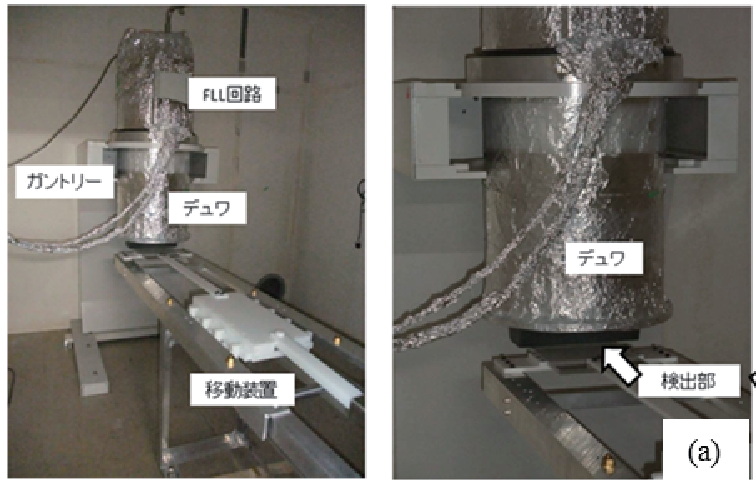

(a) $\$ 0.8 \mathrm{~mm}$ SUSz⿺⿻一⿰冫⿰亅⿱丿丶丶

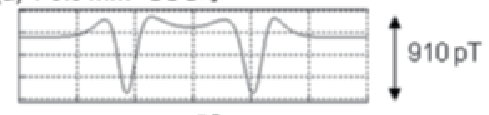

(b) $\Phi 0.3 \mathrm{~mm}$ SUSis

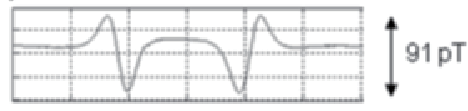

(c)被 $\$ 0.1 \mathrm{~mm}$ SUSt柆子
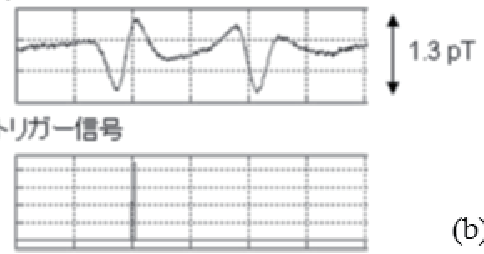

(b)

Fig. 11 (a) NDE system for magnetic contamination detection and (b) detection of SUS304 particles.

幅広検出コイル部（幅 $190 \mathrm{~mm}$ 、横 $10 \mathrm{~mm}$ ）を持つデュワ、 SQUID を動作させる FLL（Flux Locked Loop）回路、デー 夕収録用 PC とから構成されている。磁気シールドルーム 内に設置した本システムの写真を Fig. 11(a)に示す。磁気 シールド内部に移動装置とデュワを配置している。

移動装置に固定した直径が $0.8 \mathrm{~mm} 、 0.3 \mathrm{~mm}$ 、および 100 $\mu \mathrm{m}$ の SUS304 微粒子を測定した。Fig. 11(b) に示すように、 移動装置が往復運動を行うため、2つのピークが認められ る。このピークの磁場強度と異物の半径との関係を調べた 結果、異物の半径のおよそ 3 乗で磁場強度が小さくなって いくことが分かった。広めの検查対象中の微小な磁気異物 検查に幅広検出コイルは有効である。今後は、この結果を 基に HTS SQUID システムを開発していく予定である。

\section{5. おわりに}

本研究では高感度性と高い信頼性を持つ SQUID システ ムを開発し、これをバイオ計測や非破壊センシングの応用 機器へと展開寸ることを目標としている。これまでに得ら れている主な成果は以下の通りである。

磁気計測システム開発の基盤となる高温超伝導 SQUID センサの開発に関しては、積層化技術を駆使することによ り、既に、10 fT/ $/ z^{1 / 2}$ という低温 SQUID に匹敵するセンサ
性能を実現している。また検出コイル分離型 SQUID で は、開発した SQUID モジュールに用途に応じた検出コイ ルを接続すれば種々のシステム開発が可能である。このよ うな汎用性の高い SQUID モジュールの開発は本研究で初 めて開発したものである。

医療診断や再生医療のためのバイオセンシング技術とし ては、免疫検查、心臟磁気イメージング、および超低磁場 MRI のシステム開発を行っている。それぞれのシステムで は、磁気的手法の持つ優位性を示すとともに、他の競合技 術にはない性能や機能の実現を目指している。分析・評価 のための非破壊検查技術としては電池評価、水分検查、異 物検査のシステム開発を行っている。

上記のように、磁気的手法によるバイオ・非破壊検查技 術は他の競合技術では不可能な性能や機能を実現すること ができる。本チームで開発中の磁気的検査システムが実現 できればこれまでにない最新の医療・産業応用製品につな がり新規エレクトロニクス産業を創出することが期待され る。

JST の S-イノベプログラムの中の一課題として本研究を 推進している。本稿を纒めるに際して、本研究プロジェク 卜の研究分担者である、国際超電導産業技術研究センター の塚本晃氏、田辺圭一氏、日立製作所の溝口崇子氏、緒方 邦臣氏、川畑隆三氏、関悠介氏、岡山大学の紀和利彦氏、 堺健司氏、日立八イテクノロジーズの鈴木博之氏、筑波大 学の青沼和隆氏、首都大学東京の関原謙介氏の協力を得て いる。

\section{参 考 文 献}

1) S. Adachi, A. Tsukamoto, Y. Oshikubo, T. Hato, Y. Ishimaru and K. Tanabe: "Fabrication of low-noise HTS-SQUID gradiometers and magnetometers with ramp-edge Josephson junctions," IEEE Trans. Appl. Supercond. 21 (2011) 367-370

2) A. Tsukamoto, S. Adachi, Y. Oshikubo, J. Kawano, T. Hato and K. Tanabe: "Fabrication of integrated two-axis high- $T_{\mathrm{c}}$ planear gradiometer," IEEE Trans. Appl. Supercond. 21 (2011) 363-366

3) S. Adachi, A. Tsukamoto, T. Hato, J. Kawano and K. Tanabe: "Recent developments of high- $T_{\mathrm{c}}$ electronic devices with multilayer structures and ramp-edge Josephson junctions," IEICE Trans. Electron. E95-C (2012) 337-346

4) K. Enpuku, S. Hirakawa, R. Momotomi, M. Matsuo, T. Yoshida and A. Kandori: "Design of pickup coil made of Litz wire and cooled at $77 \mathrm{~K}$ for high sensitivity measurement of AC magnetic fields,” Jpn. J. Appl. Phys. 50 (2011) 076602

5) K. Enpuku, S. Hirakawa, Y. Tsuji, R. Momotomi, M. Matsuo, T. Yoshida and A. Kandori: "HTS SQUID magnetometer using resonant coupling of cooled $\mathrm{Cu}$ pickup coil," IEEE Trans. Appl. Supercond. 21 (2011) 514-517

6) H. Dong, Y. Zhang, H.J. Krause, X.M. Xie, A.I. Braginski and A. Offenhausser: "Comparison of different detecors in low field NMR measurement”, J. Phys. Conf. Ser. 234 (Part 4) (2010) 042008. 
7) H. Kuma, H. Oyamada, A. tsukamoto, T. Mizoguchi, A. Kandori, Y. Sugiura, K. Yoshinaga, K. Enpuku and N. Hamasaki: "Liquid phase immunoassays utilizing magnetic markers and SQUID magnetometer," Clin. Chem. Lab. Med. 48 (2010) 1263-1269

8) K. Enpuku, H. Watanabe, Y. Higuchi, T. Yoshida, H. Kuma, N. Hamasaki, M. Mitsunaga, H. Kanzaki and A. Kandori: "Characterization of magnetic markers for liquid-phase immunoassays using Brownian relaxation,” Jpn. J. Appl. Phys. 51 (2012) 023002

9) 圓福敬二、吉田 敬：「磁気ナノバイオセンシングの最新動 向」、電気学会誌 132 (2012) 294-297

10) J. Clarke, M. Hatridge and M. Mossle, "SQUID-detected magnetic resonance imaging in microtesla fields," Annu. Rev. Biomed. Eng. 9 (2007) 389-413.

11）福元翔平、勝 行広、鈴木美帆、森田遼介、長沼悠介、廿日 出好、田中三郎:「HTS-rf-SQUID を用いた超低磁場 MRI シ ステムの開発」、電子情報通信学会技術研究会技術研究報告 SCE2010-38, (2011) 13-16

12) S. Fukumoto, M. Hayashi, Y. Katsu, M. Suzuki, R. Morita, Y. Naganuma, Y. Hatsukade, O. Snigirev and S. Tanaka: "Liquid-state nuclear magnetic resonance measurements for imaging using HTSrf-SQUID in ultra-low field," IEEE Trans. Appl. Supercond. 21 (2011) $522-525$

13) M.M. Saari, K. Sakai, K. Kiwa, A. Tsukamoto, S. Adachi, K. Tanabe, A. Kandori and K. Tsukada: "Development of a compact moving-sample magnetometer using high- $T_{\mathrm{c}}$ superconducting quantum interference device,” Jpn. J. Appl. Phys. 51 (2012) 046601-7

14) K. Sakai, M.M. Saari, T. Kiwa, A. Tsukamoto, S. Adachi, K. Tanabe, A. Kandori and K. Tsukada: "Development of a compact DC magnetometer using HTS-SQUID and a rotating sample," Supercond. Sci. Technol. 25 (2012) 045005-10

15) T. Kiwa, S. Maeda, K. Miyake, N. Kataoka, A. Tsukamoto, S. Adachi, K. Tanabe, A. Kandori and K. Tsukada: "Differential conductivity mapping of solar panels using a high- $T_{\mathrm{c}}$ superconductor SQUID," Physica C 471 (2011) 1238-1241

16) A. Kandori, K. Ogata, R. Kawabata, S. Tanimoto and Y. Seki: "Note: Low temperature superconductor superconducting quantum interference device system with wide pickup coil for detecting small metallic particles,” Rev. Sci. Instrum. 83 (2012) 076108

圓福 敬 二 1954 年 3 月 20 日生。 1981 年 九州大学工学研

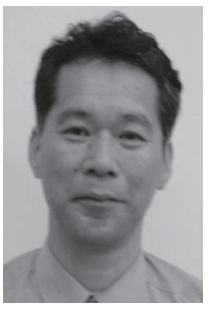
究科博士後期課程修了 (電子工学)。1981 年九 州大学勤務。2003 年同大学大学院システム情 報科学研究院・教授、超伝導システム科学研究 センター・教授 (併任)。2009 年同センター 長。超伝導センシングシステムの研究開発に従 事。低温工学・超電導学会、応用物理学会、電 子情報通信学会、磁気学会会員。工学博士。

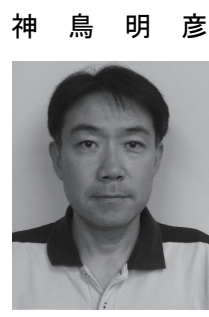

1965 年 10 月 25 日生。1 988 年上智大学理工 学部電気電子工学科卒業。1990 年同大学院理 工学研究科博士前期課程（電気電子専攻）修 了。1990 年(株) 日立製作所中央研究所勤務。 SQUID システム開発に従事。主に心臟磁気計 測システムの研究開発に従事。生体磁気学 会、応用物理学会、心電学会会員。工学博 土、医学博士。

安達成司

1961 年 2 月 3 日生。 1983 年北海道大学工学

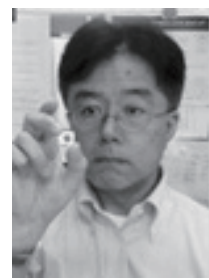
部原子工学科卒業。1 985 年同大学院工学研究 科博士前期課程（原子工学専攻）修了。1985 年松下電器産業 (株) 中央研究所勤務。ファイ ンセラミックス及び超伝導物質開発に従事。 1991 年より (財) 国際超電導産業技術研究セン ター・超電導工学研究所勤務。主に超伝導物質 及び薄膜デバイス開発に従事。現在、同研究 所主管研究員。応用物理学会、日本物理学会、日本セラミックス 協会会員。工学博士。

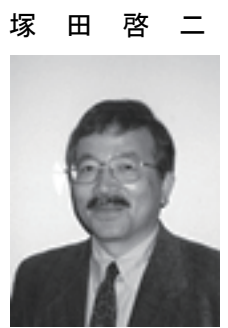

1954 年 11 月 21 日生。1979 年筑波大学自然 学類卒業。1982 年同大学院理工学研究科博士 前期課程修了。1982 年 (株) 日立製作所中央研 究所勤務。メディカルシステム研究開発に従 事。その間 1991 年より 1996 年まで(株)超伝 導センサ研究所に出向。SQUID の開発とその 医療応用研究に従事。2003 年岡山大学自然科 学研究科教授。主に超伝導デバイス応用、物 理・化学センサ、非破壊検查の研究に従事。低温工学・超電導学 会、応用物理学会、電気学会会員。工学博士、医学博士。

田中 三 郎 1958 年 9 月 16 日生。1981 年豊橋技術科学

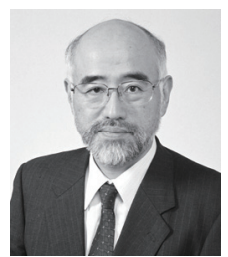
大学工学部電気電子工学課程卒業。1983 年同 大学院工学研究科修士課程（電気電子工学専 攻）修了。1983 年住友電気工業(株) 伊丹研 究所 研究員。1990 年(株)超伝導センサ研究 所主任研究員 兼務。高温超伝導 SQUID シス テム開発に従事。1995 年豊橋技術科学大学 工学部 助教授。1996 年〜1997 年カリフォル ニア州立大学バークレー校物理学科 客員研究員。2002 年同大 学 工学部 教授。応用物理学会、電気学会、静電気学会、米国 IEEE 会員。工学博士。 